\title{
ERRATUM
}

Tomoaki Ichie $\cdot$ Michiko Nakagawa

\section{Erratum to: Dynamics of mineral nutrient storage for mast reproduction in the tropical emergent tree Dryobalanops aromatica}

Published online: 18 December 2012

(C) The Ecological Society of Japan 2012

\section{Erratum to: Ecol Res \\ DOI 10.1007/s11284-011-0836-1}

In the original publication of the article, the unit of concentration for $\mathrm{N}, \mathrm{P}$ and $\mathrm{K}$ was incorrectly published as $\mathrm{mg} / \mathrm{g}$ in Fig. 1 and Table 2.

It should actually read $\mu \mathrm{g} / \mathrm{g}$ (not $\mathrm{mg} / \mathrm{g}$ ).

The online version of the original article can be found under doi:10.1007/s11284-011-0836-1.

T. Ichie $(\bowtie)$

Faculty of Agriculture, Kochi University,

Nankoku 783-8502, Japan

E-mail: ichie@kochi-u.ac.jp

Tel.: + 81-88-8645149

Fax: + 81-88-8645200

M. Nakagawa

Graduate School of Bioagricultural Sciences,

Nagoya University, Nagoya 464-8601, Japan 